Research Paper

\title{
Interleukin-35 Level Is Reduced in Patients with Chronic Hepatitis B Virus Infection
}

\author{
Sheng-Tao Cheng ${ }^{*}$, Ding Yuan ${ }^{2 *}$, Yi Liu ${ }^{3}$, Ying Huang ${ }^{3}$, Xiang Chen ${ }^{4}$, Hai-Bo Yu ${ }^{1}$, Lin He ${ }^{1}$, Hui Jiang ${ }^{1}$, \\ Ji-Hua Ren ${ }^{1}$, Juan Chen ${ }^{1 凶}$ \\ 1. Key Laboratory of Molecular Biology for Infectious Diseases (Ministry of Education), The Second Affiliated Hospital, Chongqing Medical University, \\ Chongqing Medical University, Chongqing, China \\ 2. Department of Neurosurgery, The Fifth People's Hospital of Chongqing, Chongqing, China \\ 3. Department of Infectious Diseases, The Second Affiliated Hospital, Chongqing Medical University, Chongqing, China \\ 4. Department of Clinical Laboratory, Zhuzhou Central Hospital, Zhuzhou, China \\ *These authors have contributed equally to this paper.
}

$\triangle$ Corresponding author: Professor Juan Chen, The key Laboratory of Molecular Biology of Infectious Diseases designated by the Chinese Ministry of Education, Chongqing Medical University, 1 Yixueyuan Road, Chongqing, 400016, P.R. China. E-mail: chenjuan2014@cqmu.edu.cn

( ) Ivyspring International Publisher. This is an open access article distributed under the terms of the Creative Commons Attribution (CC BY-NC) license (https://creativecommons.org/licenses/by-nc/4.0/). See http://ivyspring.com/terms for full terms and conditions.

Received: 2017.07.17; Accepted: 2017.11.13; Published: 2018.01.01

\begin{abstract}
Backgrounds: As one of the major public health problems, the hepatitis B virus (HBV) infection would activate the immune system. The outcome of HBV infection was affect significantly by the interactions between $\mathrm{HBV}$ and host immune response. Interleukins play important role in anti-viral immunity. Here we investigated the role of interleukin-35 (IL-35) in chronic HBV infection patients.

Methods/Results: Serum IL-35 in 72 chronic hepatitis B virus infection patients and 41 healthy control subjects were analyzed by ELISA assay. The mRNA level of IL-35 in PBMCs was determined by RT-qPCR. In this study, we found that both protein and mRNA levels of IL-35 were significantly decreased in chronic HBV patients compared to the healthy controls. Furthermore, the statistical analysis found that serum IL-35 was significantly associated with HBV DNA $(P=0.0158)$, ALT ( $P$ $=0.0003)$, AST $(P=0.0216)$, TB $(P=0.0270)$ and AFP $(P=0.0369)$. Importantly, correlation analysis also found that serum IL-35 level was negatively correlated with HBV DNA copies, ALT, AST, TB and AFP. Meanwhile, IL-35 treatment inhibited the level of HBV DNA, HBsAg and HBeAg in HepAD38 cells.
\end{abstract}

Conclusion: Our study identified that IL-35 may be a novel marker associated with HBV infection and hepatocytes injury. These data suggested the potential use of IL-35 in the HBV treatment.

Key words: Interleukin-35, Hepatitis B virus

\section{Introduction}

Chronic hepatitis B virus infection is a major global health problem. Approximately 2 billion people have been infected with hepatitis $B$ virus (HBV) and 350-400 million people have been identified as carriers of the chronic HBV [1]. HBV consists of a $3.2 \mathrm{~kb}$ partially double-stranded, relaxed-circular DNA (rcDNA) genome. The rcDNA could converted into covalently closed circular DNA (cccDNA) which serve as the template for the synthesis of all viral RNAs, including the $3.5 \mathrm{~kb}, 2.4 \mathrm{~kb}$, $2.1 \mathrm{~kb}$ and $0.7 \mathrm{~kb}$ mRNAs. Although HBV is a DNA virus, there is reverse transcription process in HBV life cycle. Briefly, the pregenomic RNA (3.5kb mRNA) could reverse transcript to generate DNA. And the DNA is further encapsulated by viral proteins to form mature viral particles which would be the potential reason for the failure of viral clearance and relapse of viral activity [2]. It is reported that $\mathrm{HBV}$ infection could activate the immune system and induce extensive inflammatory response. Growing evidence supported that cytokine-mediated immune response plays an important role in clinical outcomes of $\mathrm{HBV}$ 
infection [3] [4]. Many immune factors were involved in the HBV infection including classical immune factors, transforming growth factor- $\beta$ (TGF- $\beta$ ) [5], tumor necrosis factor- $\alpha$ (TNF- $\alpha$ ) [6], and members of the interleukin family such as interleukin-6 [7] and interluekin-23 [8].

Interleukin-35 (IL-35) has been recognized as a novel member of IL-12 family which composed of IL-12 $\alpha$ and IL-27 $\beta$ chains and encoded by two separate genes called IL-12A and EBI3, respectively. IL-35 is a responsive anti-inflammatory cytokine [9] implicated in many pathology processes. It has been reported that serum IL-35 level was significantly decreased in patients with acute motor axonal neuropathy [10] and rheumatoid arthritis [11]. Meanwhile, other studies showed that elevated serum levels of IL-35 associated with the immune tolerance in normal pregnancy [12] and autoimmune encephalomyelitis [13]. As for virus, interleukin-35 is upregulated in response to influenza virus infection [14]. However, the association between IL-35 and HBV infection has not been reported yet. In this study, we analyzed the relationship between IL- 35 and HBV infection. Serum IL-35 and IL-35 mRNA were significantly downregulated in chronic HBV patients compared to the healthy controls. Serum IL-35 was significantly associated with HBV DNA, ALT, AST, TB and AFP. This research aims to understand the interactions between the IL-35 and the virus in vivo, providing a new aspect for the prevention and treatment of the virus.

\section{Materials and methods}

\section{Patients selection}

This study examined 72 cases chronic hepatitis B virus infection patients including 31 cases hepatitis $B$ virus e antigen ( $\mathrm{HBeAg}$ ) positive and 41 cases $\mathrm{HBeAg}$ negative ones. All patients were hepatitis $B$ virus $s$ antigen (HBsAg) positive. The patients with other virus infection (hepatitis $C$ virus, hepatitis $D$ virus, human immunodeficiency virus type 1 [HIV-1], and HIV-2) were excluded. These patients were not suffering from any other chronic liver disease or autoimmune disease. Relevant pathological information and outcome data were collected retrospectively. 41 sex- and age-matched healthy subjects were recruited as normal control group. Informed consents were obtained from each patient. This study was approved by the Clinical Research Ethics Committee of the Chongqing Medical University.

\section{Enzyme linked immunosorbent assay (ELISA)}

The chronic HBV infection patients' full blood were collected and centrifuged to obtain the serum.
Serum levels of IL-35 in patients were determined by IL-35 ELISA kits (Catalog no. JYM2045Hu, ColorfulGene Biological Technology, Wuhan, China) according to the manufacturer's instructions.

The cell culture medium was collected at the indicated time point and the level of HBsAg and HBeAg were detected by ELISA kits (KHB).

\section{Peripheral blood mononuclear cells (PBMCs) preparation}

The PBMCs were isolated from blood of chronic HBV patients by using Ficoll kit (Catalog no. LTS1077).

\section{Real-time PCR}

The total RNAs in PBMCs were extracted by TRNzol (Catalog no. P5019, TIANGEN, Beijing, China) methods. The expression values of target genes were determined according to the $2^{-\triangle \Delta C t}$ method [15]. The following primers were used for RT-qPCR: IL-35 specific primers: forward primer, 5'-TGTTCTCCATGGCTCCCTA-3', reverse primer, 5'-TTATGAAAGGCACGAAGCTG-3'. $\beta$-actin specific primers: forward primer, 5'-CTCTTCCAGCCTTCC TTCCT-3', reverse primer, 5'-AGCACTGTGTTGG CGTACAG-3'.

The absolute quantification of the HBV DNA was detected using Fast Start Universal SYBR Green Master (Catalog no. 06924204001, Roche, Mannheim, Germany). The sequences of the primers are as follows: forward, $5^{\prime}$-CCTAGTAGTCAGTTATGTCAA C-3', reverse, 5'-TCTATAAGCTGGAGGAGTGCGA$3^{\prime}$.

\section{Cell culture}

HepAD38 cells were purchased from the Shanghai Second Military Medical University and cultured in Dulbecco's modified Eagle medium (DMEM) (Catalog no. 10-010-CVR, Corning, New York, USA) with $10 \%$ fetal bovine serum (FBS) and $400 \mathrm{ug}$ of G418 (Catalog no. 345810, Merck, Germany) per $\mathrm{ml}$.

\section{Statistical analysis}

Results of patients are expressed as medium (interquartile range). Manne-Whitney rank test was used to assess the difference between two groups. Correlations between IL-35 and clinicopathologic parameters were analyzed by Spearman's rank test and nonparametric $\chi^{2}$ test. Results of cell models are expressed as mean $\pm S D$ and compared by the Student's t-test. $P<0.05$ was considered statistically different. The SPSS 19.0 software was used to analyze the data. 


\section{Results}

\section{Characteristics of the subjects enrolled in the study}

This study consisted of 72 chronic HBV patients and 41 healthy control subjects. The clinical background of the patients and healthy controls were described in Table 1. As shown in Table 1, all the patients in HBV group were HBsAg and HBV DNA positive. Comparison with control group, the serum level of total protein and albumin in HBV group were obviously decreased. As the total protein and albumin is mainly synthesized in liver, the decreased level of those two proteins suggesting the impaired physiological function of the liver. Furthermore, liver injury index was detected. The serum concentrations of alkanine aminotransferase (ALT), aspartate aminotransferase (AST), total bilirubin (TB), direct bilirubin (DB) and alpha-fetoprotein (AFP) were significantly increased in chronic HBV patient group compared to the healthy control group, indicating the hepatocytes injury caused by HBV infection.

\section{IL-35 expression in HBV patients}

To investigate whether IL-35 plays a role in the process of HBV infection, we first determined the serum concentrations of IL-35 in HBV patients (Figure 1A). The serum IL-35 in HBV patient group (median: $107.01 \mathrm{pg} / \mathrm{ml}$ ) was significantly decreased compared to control group (median: $190.41 \mathrm{pg} / \mathrm{ml}$ ), which suggesting the potential relationship between IL-35 and HBV infection. For further study, we isolated the PBMCs from patients. Total RNAs were extracted and the mRNA level of IL-35 was determined by RT-qPCR (Figure 1B). Consistently, the mRNA levels of IL-35 in PBMCs from HBV patients were markedly decreased compared to healthy subjects. These data suggested that IL-35 play an important role in the process of HBV infection.
Table 1. Clinical and virological characteristics of the subjects enrolled in the study.

\begin{tabular}{|c|c|c|c|}
\hline Baseline characteristics & $\begin{array}{l}\text { Healthy controls } \\
(n=41)\end{array}$ & $\begin{array}{l}\text { Chronic hepatitis } \\
\text { B } \\
(n=72)\end{array}$ & $\begin{array}{l}P \\
\text { value }\end{array}$ \\
\hline Age, years & $39(24-61)$ & $35(18-69)$ & ns \\
\hline Male/female & $18 / 23$ & $38 / 34$ & ns \\
\hline HBsAg positive & $0 / 41$ & $72 / 72$ & \\
\hline HBeAg positive & $0 / 41$ & $31 / 72$ & \\
\hline $\mathrm{HBcAb}$ positive & $0 / 41$ & $18 / 72$ & \\
\hline $\begin{array}{l}\text { Total protein } \mathrm{g} / \mathrm{L} \text { [median } \\
\text { (IQ range)] }\end{array}$ & $75.3(67.3-82.6)$ & $69.9(49.2-91.5)$ & 0.0004 \\
\hline $\begin{array}{l}\text { Albumin g/L [median (IQ } \\
\text { range)] }\end{array}$ & $50.5(45.7-56.4)$ & $38.2(25.4-48.5)$ & $<0.0001$ \\
\hline $\begin{array}{l}\text { ALT, U/L [median (IQ } \\
\text { range)] }\end{array}$ & $17(4-54)$ & $389(25-1792)$ & $<0.0001$ \\
\hline $\begin{array}{l}\text { AST, U/L [median (IQ } \\
\text { range)] }\end{array}$ & $22(11-36)$ & $195(19-1539)$ & $<0.0001$ \\
\hline $\begin{array}{l}\mathrm{TB}, \mu \mathrm{mol} / \mathrm{L} \text { [median (IQ } \\
\text { range)] }\end{array}$ & $11.30(4.80-39.29)$ & $\begin{array}{l}56.00 \\
(5.6 .00-613.00)\end{array}$ & $<0.0001$ \\
\hline $\begin{array}{l}\mathrm{DB}, \mu \mathrm{mol} / \mathrm{L} \text { [median (IQ } \\
\text { range)] }\end{array}$ & $2.76(1.20-10.37)$ & $35.00(1.50-437.00)$ & $<0.0001$ \\
\hline $\mathrm{AFP}, \mathrm{ug} / \mathrm{L}$ & $0.24(0.01-7.85)$ & $61.80(2.78-377.80)$ & $<0.0001$ \\
\hline HBV DNA $\log 10(\mathrm{IU} / \mathrm{ml})$ & 0 & $5.68(3.00-9.24)$ & \\
\hline Autoimmune diseases & None & None & \\
\hline
\end{tabular}

\section{Correlation between IL-35 expression and HBV DNA copies}

The HBV genome is a relaxed circular partially double-stranded DNA (rcDNA) of approximately 3200bp. Determination of the serum HBV DNA level could predict the efficacy of antiviral therapy [16] [17]. Therefore, we analyzed the correlation of IL-35 and HBV DNA copies (Figure 2A). The serum concentrations of IL-35 was negatively correlated with HBV DNA copies (Speraman's rank $=-0.2836, p=$ 0.0158). These data indicated that determination of the levels of IL-35 could provide crucial information to point the HBV DNA level.
A

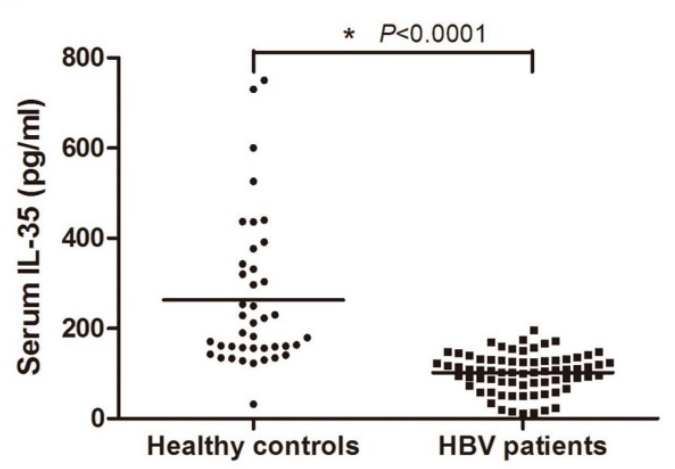

B

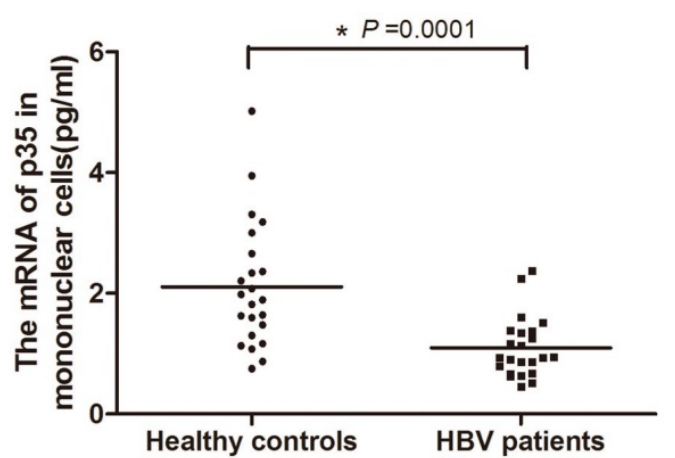

Figure 1. IL-35 expression in HBV patients. (A) The serum IL-35 were determined by ELISA assay both in HBV patients and healthy controls. (B) The mRNA level of IL-35 in PBMCs were detected by RT-qPCR. The $\beta$-actin was used as the internal control. 


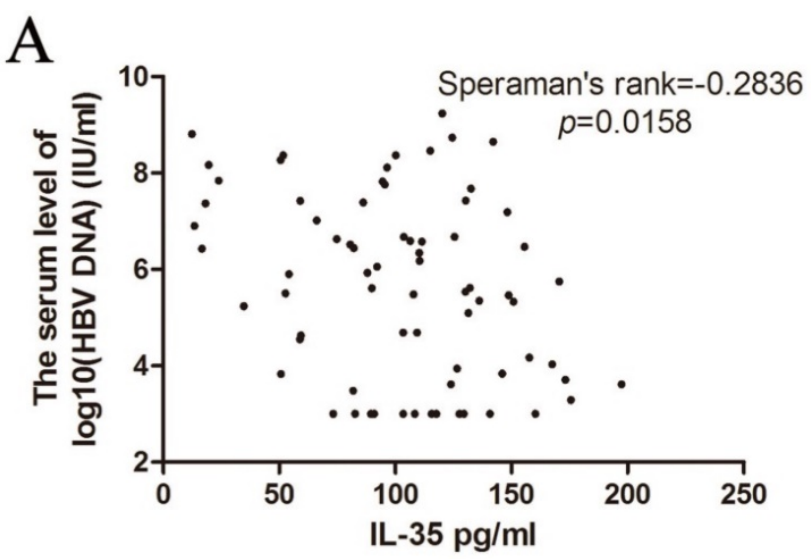

Figure 2. The correlation of HBV DNA copies with IL-35 expression was analyzed by Speraman's rank test.

\section{The correlation between IL-35 and liver injuries}

ALT, AST, TB and DB are the common index to reflect the liver damage in clinical practice. Therefore, we studied the association between IL-35 expression and liver injuries (Figure 3A-D). We found that there was a negative correlation between IL-35 and liver injury markers (ALT: Speraman's rank $=-0.4161, p=$ 0.0003; AST: Speraman's rank $=-0.2704, p=0.0216$; TB: Speraman's rank $=-0.2607, p=0.0270$ ). All the results demonstrated that IL-35 might be involved in the pathological process of $\mathrm{HBV}$ infection and related liver injury.

Considering that HBV infection is one of the leading causes of hepatocellular carcinoma (HCC) [18], we also analyzed the HCC marker AFP. IL-35 was negatively related to AFP concentration (Figure $3 \mathrm{E}$, Speraman's rank $=-0.2464, p=0.0369$ ). These data indicated that IL-35 may be used for HBV prognosis prediction.

\section{Correlation between IL-35 and clinical parameters in chronic HBV patients}

To elucidate the potential correlation between IL-35 and clinical parameters, we divided the HBV patients into two groups (low expression: IL-35<100 $\mathrm{pg} / \mathrm{ml}$, high expression: IL-35>100 pg/ml) according to the serum concentrations of IL-35. Table 2 provided an overview of the included analyses. Among the 72 cases, 31 cases showed low expression of IL-35 and 41 cases showed high expression of IL-35. As shown in Table 2, ALT $(p=0.0082)$, AST $(p=$ $0.0192)$, TB $(p=0.0445), \mathrm{DB}(p=0.0265), \operatorname{AFP}(p=$ $0.0489)$ and HBV DNA $(p=0.0489)$ were significantly associated with serum IL-35. Taken together, those data suggested that IL-35 plays an important role in the interaction between HBV infection and host response.

\section{IL-35 inhibited HBV replication in vitro}

HepAD38 cells can stably expressing HBV where $\mathrm{HBV}$ genome integrates into host genome and the expression of $\mathrm{HBV}$ can be regulated by tetracycline. To further explore the functional role of IL-35 in HBV replication in vitro, HepAD38 cells were treated with different concentrations of rhIL-35 and the level of HBV DNA replicative intermediates were detected by real-time PCR (Figure 4A). As shown in Figure 4A, IL-35 treatment resulted in decreased of HBV DNA level. Furthermore, the secretion levels of HBsAg and $\mathrm{HBeAg}$ in supernatant were moderately decreased which detected by ELISA assay (Figure 4B-C).

Table 2. Correlative analysis of serum IL-35 level with clincopathologic features in chronic HBV patients.

\begin{tabular}{|c|c|c|c|}
\hline \multirow[b]{2}{*}{ Clincopathologic features } & \multicolumn{2}{|c|}{ IL-35 Expression } & \multirow[b]{2}{*}{$P$ value } \\
\hline & $\begin{array}{l}\text { Low } \\
(\mathrm{n}=31)\end{array}$ & $\begin{array}{l}\text { High } \\
(\mathrm{n}=41)\end{array}$ & \\
\hline \multicolumn{4}{|l|}{ HBeAg } \\
\hline Negative & 11 & 15 & 1.0000 \\
\hline Positive & 20 & 26 & \\
\hline \multicolumn{4}{|l|}{ ALT, U/L } \\
\hline$<100$ & 0 & 9 & 0.0082 \\
\hline$>100$ & 31 & 32 & \\
\hline \multicolumn{4}{|l|}{ AST, U/L } \\
\hline$<100$ & 5 & 15 & 0.0192 \\
\hline$>100$ & 36 & 26 & \\
\hline \multicolumn{4}{|l|}{$\mathrm{TB}, \mu \mathrm{mol} / \mathrm{L}$} \\
\hline$<100$ & 17 & 32 & 0.0445 \\
\hline$>100$ & 14 & 9 & \\
\hline \multicolumn{4}{|l|}{$\mathrm{DB}, \mu \mathrm{mol} / \mathrm{L}$} \\
\hline$<100$ & 19 & 35 & 0.0265 \\
\hline$>100$ & 12 & 6 & \\
\hline \multicolumn{4}{|l|}{$\mathrm{AFP}, \mathrm{ug} / \mathrm{L}$} \\
\hline$<20$ & 7 & 19 & 0.0489 \\
\hline$>20$ & 24 & 22 & \\
\hline \multicolumn{4}{|l|}{ HBV DNA $\log 10(\mathrm{IU} / \mathrm{ml})$} \\
\hline$<5$ & 7 & 19 & 0.0489 \\
\hline$>5$ & 24 & 22 & \\
\hline
\end{tabular}

\section{Discussion}

As HBV is a non-cytopathic virus, immune-mediated host reactions play a pivotal role in both HBV-related liver damage and viral control. IL-12 family includes interleukin-6 (IL-6), interleukin-12 (IL-12), interleukin-23 (IL-23), interleukin-27 (IL-27) and interleukin-35 (IL-35). Many members of this family are reported to be involved in the HBV infection. IL-6 expression is upregulated by hepatitis $\mathrm{B}$ virus core antigen and middle $\mathrm{S}$ antigen via p38 MAPK/NF- $\mathrm{kB}$ pathways [19] [20]. Meanwhile, serum IL-23 level in HBeAg-positive HBV infection patients before therapy could be used to predict the therapeutic response to interferon (IFN) [21]. In addition, serum IL-27 is elevated in HBV patients [22] and IL-27 treatment could inhibit HBV replication [23]. It is also 
reported that IL-12 expression in HBV patients is significantly different from the healthy subjects [24]. However, the relationship between IL-35 and HBV replication has not been reported yet. In this study, we found that serum IL-35 and IL-35 mRNA were significantly decreased in chronic HBV infection patients, suggesting the possible role of IL-35 in HBV infection.

In the field of hepatitis virus, Langhans et al. [25] have reported that hepatitis $\mathrm{C}$ virus $(\mathrm{HCV})$ core specific Treg cells could suppress the immune response through IL-35, indicating that IL-35 may serve as an immune suppressor in HCV infection. To further elucidate the function of abnormally expression of IL-35 in HBV infection patients, we analyzed the correlations between IL-35 concentration

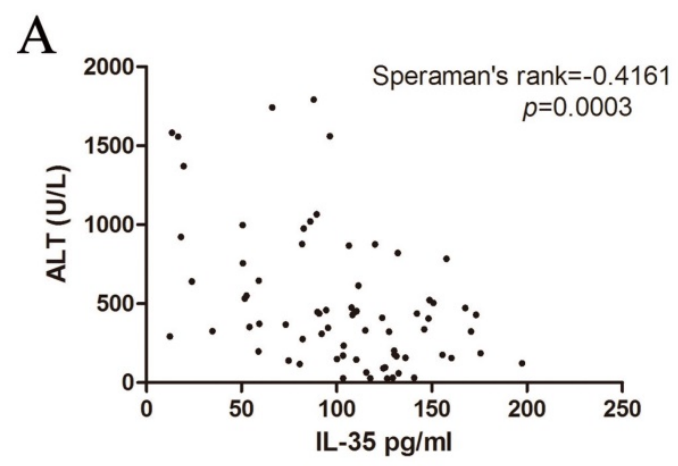

C

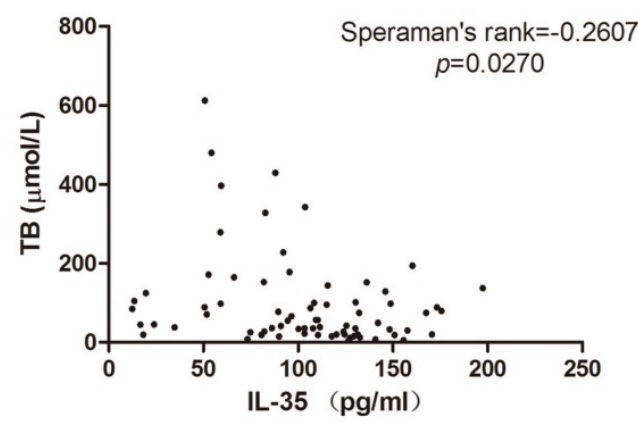

$\mathrm{E}$

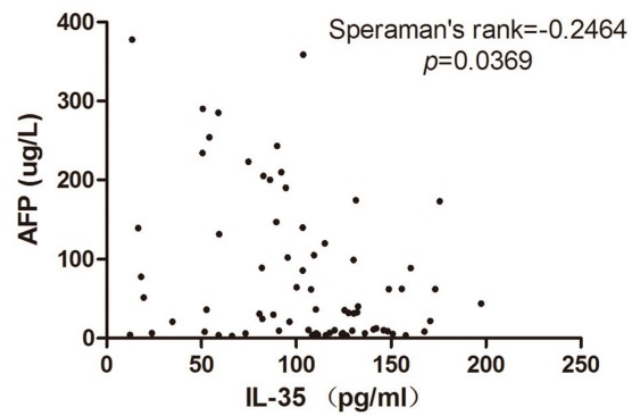

and liver injury markers. Due to the differences in patient screening criteria and the restrictions of patient number, Shi $\mathrm{M}$ et al. [26] found that serum IL-35 levels in patients with hepatitis B-related liver cirrhosis were negatively correlated with albumin, but not with ALT. However, our study found that serum IL-35 level negatively correlated with ALT and AST. The correlation between IL-35 and ALT and AST demonstrated the possibility that IL-35 may work as a new marker of liver damage. In addition, some studies report that IL-35 is associated with hepatocellular carcinoma (HCC) progression [27], aggressiveness and recurrence [28] which support our finding that IL-35 was negatively related to tumor marker AFP.
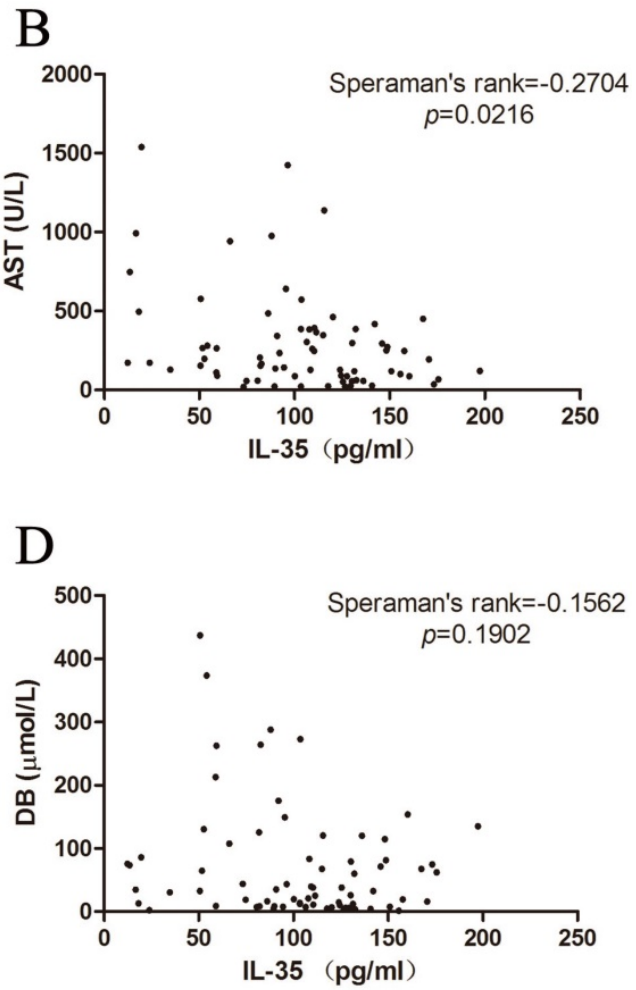
A

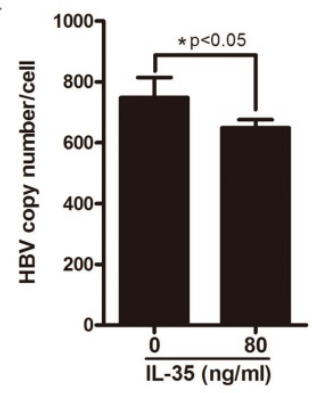

C

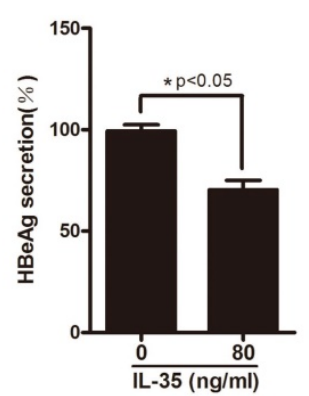

Figure 4. IL-35 inhibited HBV replication in vitro. HepAD38 cells were treated with IL-35. (A) The level of HBV DNA was detected by absolute quantification PCR. (B-C) The secretion level of $\mathrm{HBsAg}(\mathrm{B})$ and $\mathrm{HBeAg}(\mathrm{C})$ in supernatants were determined by ELISA assay.

The recent studies demonstrate that IL-35 could function through multiple pathways. It is reported that increased interleukin-35 level in colorectal cancer could activate STAT1/STAT3 to suppress $\mathrm{T}$ cell proliferation [29]. Meanwhile, Epstein-Barr virus-induced gene 3 (EBI3), the subunit of IL-35, may assist the tumor escape immune surveillance via STAT3 signaling pathway [30]. Importantly, the STATx pathways is involved in the pathology process of HBV infection. Matrix metalloproteinase-9 (MMP-9) could repress the STAT signaling pathway to facilitates HBV replication [31]. Additionally, IL-6 could reactivate $\mathrm{HBV}$ in liver through STAT3 signaling pathway [32]. In vitro, ubiquitin-specific protease 18 [33], transmembrane protein TMEM2 [34] and the novel liver-targeting interferon (IFN-CSP) [35] could inhibit the HBV infection through the JAK-STAT signaling pathway. The above studies strongly suggest that IL-35 may regulate the HBV infection through STATx pathways.

PBMCs play an important role in anti-viral responses. In vivo, it has found that the dysfunction of PBMC may monitor HBV load and the immune states to regulate the HBV chronic infection and tolerance [36]. In vitro, it showed that PBMC-derived dendritic cells from $\mathrm{HBV}$ patients would suppress $\mathrm{HBV}$ replication [37]. Consistently, our data showed that the IL-35 mRNA in PBMCs of chronic HBV patients was obviously decreased compared to healthy subjects. This change would alter the immune response to $\mathrm{HBV}$ infection.

In summary, this study deeps our understanding of the role of IL-35 in HBV infection, especially on the outcomes and clinical significance of HBV infection. The relationship between IL-35 and clinical parameters may be a potential marker in HBV infection. Further studies are needed to investigate the underlying mechanism of IL-35 in HBV infection.

\section{Acknowledgements}

All the authors declare no potential conflicts of interest. This study was supported by the National Natural Science Foundation of China $(81672012$, JC) and Chongqing Natural Science Foundation (cstc2016jcyjA0183, JC).

\section{Research and ethical clearance}

The Clinical Research Ethics Committee of the Chongqing Medical University approved the clinical research.

\section{Competing Interests}

The authors have declared that no competing interest exists.

\section{References}

1. European Association For The Study Of The L. EASL clinical practice guidelines: Management of chronic hepatitis B virus infection. Journal of hepatology. 2012; 57: 167-85.

2. Wang J, Shen T, Huang X, Kumar GR, Chen X, Zeng Z, et al. Serum hepatitis B virus RNA is encapsidated pregenome RNA that may be associated with persistence of viral infection and rebound. Journal of hepatology. 2016; 65: 700-10.

3. Bertoletti A, Ferrari C. Innate and adaptive immune responses in chronic hepatitis B virus infections: towards restoration of immune control of viral infection. Gut. 2012; 61: 1754-64.

4. Seetharam A, Perrillo R, Gish R. Immunosuppression in Patients with Chronic Hepatitis B. Current hepatology reports. 2014; 13: 235-44.

5. Pang J, Zhang G, Lin Y, Xie Z, Liu H, Tang L, et al. Transforming growth factor beta-activated kinase 1 transcriptionally suppresses hepatitis B virus replication. Scientific reports. 2017; 7: 39901.

6. Matsumoto T, Takahashi K, Inuzuka T, Kim SK, Kurosaki T, Kawakami S, et al. Activation of TNF-alpha-AID axis and co-inhibitory signals in coordination with Th1-type immunity in a mouse model recapitulating hepatitis B. Antiviral research. 2017; 139: 138-45.

7. Attar M, Azar SS, Shahbazi M. Interleukin-6-174 Promoter Polymorphism and Susceptibility to Hepatitis B Virus Infection as a Risk Factor for Hepatocellular Carcinoma in Iran. Asian Pacific journal of cancer prevention : APJCP. 2016; 17: 2395-9.

8. Bao S, Zheng J, Li N, Huang C, Chen M, Cheng Q, et al. Role of interleukin-23 in monocyte-derived dendritic cells of HBV-related acute-on-chronic liver failure and its correlation with the severity of liver damage. Clinics and research in hepatology and gastroenterology. 2016.

9. Li X, Mai J, Virtue A, Yin Y, Gong R, Sha X, et al. IL-35 is a novel responsive anti-inflammatory cytokine--a new system of categorizing anti-inflammatory cytokines. PloS one. 2012; 7: e33628.

10. Zhang LJ, Guo HY, Zhang DQ, Wang R, Li T, Li LM, et al. Analysis of serum interleukin-27 and interleukin-35 concentrations in patients with Guillain-Barre syndrome. Clinica chimica acta; international journal of clinical chemistry. 2017; 468: 5-9.

11. Ning $X$, Jian Z, Wang W. Low Serum Levels of Interleukin 35 in Patients with Rheumatoid Arthritis. The Tohoku journal of experimental medicine. 2015; 237: 77-82.

12. Yue CY, Zhang B, Ying CM. Elevated Serum Level of IL-35 Associated with the Maintenance of Maternal-Fetal Immune Tolerance in Normal Pregnancy. PloS one. 2015; 10: e0128219.

13. Liu JQ, Liu Z, Zhang X, Shi Y, Talebian F, Carl JW, Jr., et al. Increased Th17 and regulatory $\mathrm{T}$ cell responses in EBV-induced gene 3-deficient mice lead to 
marginally enhanced development of autoimmune encephalomyelitis. Journal of immunology. 2012; 188: 3099-106.

14. Chen Y, Wang CJ, Lin SH, Zhang M, Li SY, Xu F. Interleukin-35 is upregulated in response to influenza virus infection and secondary bacterial pneumonia. Cytokine. 2016; 81: 23-7.

15. Livak KJ, Schmittgen TD. Analysis of relative gene expression data using real-time quantitative PCR and the 2(-Delta Delta C(T)) Method. Methods (San Diego, Calif). 2001; 25: 402-8.

16. Degertekin B, Lok AS. Indications for therapy in hepatitis B. Hepatology. 2009; 49: S129-37.

17. Lim SG, Mohammed R, Yuen MF, Kao JH. Prevention of hepatocellular carcinoma in hepatitis B virus infection. Journal of gastroenterology and hepatology. 2009; 24: 1352-7.

18. Ott JJ, Stevens GA, Groeger J, Wiersma ST. Global epidemiology of hepatitis B virus infection: new estimates of age-specific HBsAg seroprevalence and endemicity. Vaccine. 2012; 30: 2212-9.

19. Chen Z, Li YX, Fu HJ, Ren YL, Zou L, Shen SZ, et al. Hepatitis B Virus Core Antigen Stimulates IL-6 Expression via p38, ERK and NF-kappaB Pathways in Hepatocytes. Cellular physiology and biochemistry : international journal of experimental cellular physiology, biochemistry, and pharmacology. 2017; 41: 91-100.

20. Li YX, Ren YL, Fu HJ, Zou L, Yang Y, Chen Z. Hepatitis B Virus Middle Protein Enhances IL-6 Production via p38 MAPK/NF-kappaB Pathways in an ER Stress-Dependent Manner. PloS one. 2016; 11: e0159089.

21. Yu C, Gong X, Yang Q, Lian J, Xu K, Ruan B, et al. The serum IL-23 level predicts the response to pegylated interferon therapy in patients with chronic hepatitis B. Liver international : official journal of the International Association for the Study of the Liver. 2015; 35: 1549-56.

22. Wang HL, Zhang HY, Zhai ZL, Zhou X. The correlation between hepatitis $B$ virus infection and IL-27. Bio-medical materials and engineering. 2012; 22: 187-93.

23. Tan G, Xiao Q, Song H, Ma F, Xu F, Peng D, et al. Type I IFN augments IL-27-dependent TRIM25 expression to inhibit HBV replication. Cellular \& molecular immunology. 2017.

24. Zare A, Rashki A, Ghahari S, Ghayoori B. The analysis of correlation between IL-12 gene expression and hepatitis B virus in the affected patients. Virusdisease. 2015; 26: 196-9.

25. Langhans B, Braunschweiger I, Arndt S, Schulte W, Satoguina J, Layland LE, et al. Core-specific adaptive regulatory T-cells in different outcomes of hepatitis C. Clinical science. 2010; 119: 97-109.

26. Shi M, Wei J, Dong J, Meng W, Ma J, Wang T, et al. Function of interleukin-17 and -35 in the blood of patients with hepatitis B-related liver cirrhosis. Molecular medicine reports. 2015; 11: 121-6.

27. Long J, Guo H, Cui S, Zhang H, Liu X, Li D, et al. IL-35 expression in hepatocellular carcinoma cells is associated with tumor progression. Oncotarget. 2016; 7: 45678-86.

28. Fu YP, Yi Y, Cai XY, Sun J, Ni XC, He HW, et al. Overexpression of interleukin-35 associates with hepatocellular carcinoma aggressiveness and recurrence after curative resection. British journal of cancer. 2016; 114: 767-76.

29. Ma Y, Chen L, Xie G, Zhou Y, Yue C, Yuan X, et al. Elevated level of interleukin- 35 in colorectal cancer induces conversion of $\mathrm{T}$ cells into iTr35 by activating STAT1/STAT3. Oncotarget. 2016; 7: 73003-15.

30. Liang Y, Chen Q, Du W, Chen C, Li F, Yang J, et al. Epstein-Barr Virus-Induced Gene 3 (EBI3) Blocking Leads to Induce Antitumor Cytotoxic T Lymphocyte Response and Suppress Tumor Growth in Colorectal Cancer by Bidirectional Reciprocal-Regulation STAT3 Signaling Pathway. Mediators of inflammation. 2016; 2016: 3214105.

31. Chen J, Xu W, Chen Y, Xie X, Zhang Y, Ma C, et al. MMP-9 Facilitates Hepatitis B Virus Replication through Binding with IFNAR1 to Repress IFN/JAK/STAT Signaling. Journal of virology. 2017.

32. Chou CH, Chen PJ, Jeng YM, Cheng AL, Huang LR, Cheng JC. Synergistic effect of radiation and interleukin-6 on hepatitis B virus reactivation in liver through STAT3 signaling pathway. International journal of radiation oncology, biology, physics. 2009; 75: 1545-52.

33. Li L, Lei QS, Zhang SJ, Kong LN, Qin B. Suppression of USP18 Potentiates the Anti-HBV Activity of Interferon Alpha in HepG2.2.15 Cells via JAK/STAT Signaling. PloS one. 2016; 11: e0156496.

34. Zhu X, Xie C, Li YM, Huang ZL, Zhao QY, Hu ZX, et al. TMEM2 inhibits hepatitis B virus infection in HepG2 and HepG2.2.15 cells by activating the JAK-STAT signaling pathway. Cell death \& disease. 2016; 7: e2239.

35. Lu X, Wang J, Jin X, Huang Y, Zeng W, Zhu J. IFN-CSP inhibiting hepatitis B virus in HepG2.2.15 cells involves JAK-STAT signal pathway. BioMed research international. 2015; 2015: 959684

36. Peng $\mathrm{Y}$, Xiong $X$, Tong $X, \mathrm{Li}$ M, Yang $X, \mathrm{Hu}$ G, et al. Correlation of the content of hepatitis $\mathrm{B}$ core antigen in peripheral blood mononuclear cells with HBV virus load. Diagnostic microbiology and infectious disease. 2016; 85: 154-8.

37. Liu T, Song HL, Zheng WP, Shen ZY. Inhibition of HBV Replication in HepG2.2.15 Cells by Human Peripheral Blood Mononuclear Cell-Derived Dendritic Cells. Annals of clinical and laboratory science. 2015; 45: 495-501. 